\title{
E-Learning Innovation in Indonesia: Journal Sharing of Critical Care (JSCC) for Nursing Students in the Pandemic Covid-19
}

\author{
Heru Suwardianto ${ }^{1,2,3}$, Vitaria W.A. ${ }^{3}$ \\ ${ }^{1}$ Associate Lecturer, Certified Expertise Critical Care (CECC), ${ }^{2}$ Indonesian Critical Care Nurses Association \\ (ICCNA), ${ }^{3}$ Baptist Hospital Health Collage in Kediri Indonesia
}

\begin{abstract}
The challenge during the COVID-19 pandemic was Nursing Students studying at home. The innovation of e-learning encourages Clinical Reasoning, patient safety, self-actualization, clinical decision, professionalism, and, competences. The purpose of this study was to determine the effectiveness of the E-Learning Innovation: Journal of Sharing Critical Care (JSCC) in Critical Nursing Students during the Pandemic COVID-19.
\end{abstract}

Research Design uses Descriptive Analysis. The population was all professional nursing students. The sample size was 39 respondents using purposive sampling. Inclusion criteria are students who can complete the learning process for 2 weeks. The independent variable was JSCC. The dependent variable was primary assessment, diagnostic procedures, nursing care, Soft skills, and Outcome. Instrument use Edlink Application. Data analysis uses Partial Least Square (PLS).

The results showed that the variable The ability to explain theory had a positive relationship with The ability to make nursing care $(\rho=0,000)$, primary assessment with the ability to make nursing care $(\rho=0,000)$, The ability to explain diagnostic procedures with nursing care $(\rho=0,000)$, The ability to make nursing care with Soft skill $(\rho=0,000)$, and soft skill has with Outcome $(\rho=0,000)$ with t statistic $>1.96$ in The ability to make nursing care $(\mathrm{t}$ statistic $=25,273)$, Soft skill $(\mathrm{t}$ statistic $=8,15)$, Outcome $(\mathrm{t}$ statistic $=9,267)$.

The innovation of learning method using e-learning journal sharing of critical care has a positive impact on explaining deeper cases, strengthening learning competencies, and critical thinking.

Keywords: e-hearing, critical nursing, journal sharing.

\section{Introduction}

Pandemic COVID-19 is an outbreak of coronavirus disease 2019 (COVID-19) which attacks many victims globally as well as in Indonesia ${ }^{1,2}$. The cause of the Plague was due to the rapid spread of COVID-19 to various countries and caused many deaths. The reason is because of the rapid spread of COVID-19 which is easily transmitted through saliva splashing or maybe also airborne. The plague is certain to continue to increase with the increase in COVID-19 victims, the Indonesian government in May 2020 issued a policy to work, worship, and study at home ${ }^{3}$. Local governments also follow the recommendations of the central government by making circulars related to physical distancing, using masks when leaving the house, washing hands with soap and running water, studying at home, worshiping at home, and working at home. The world of nursing education in Indonesia is also affected by government policy, so lecturers must innovate in the learning process at home for a long time. Nursing students who are currently going through the education process are also affected because of the COVID-19 Pandemic. The impact is felt by every student and lecturer in the learning process in Indonesia. The impact that is seen through the learning process is the change in learning method in nursing students who were initially conventional and are now fully engaged in using e-learning innovations. Nursing students are currently enrolled in critical nursing 
courses. Students have different challenges in 2020 in completing assignments and completing the existing learning process. Critical nursing students must also complete the workload they get during the COVID-19 Pandemic. If this pandemic is not finished soon, the learning process will be hampered and the need for learning innovations to find the best solution without leaving aside the competencies obtained by students.

WHO data on May 8, 2020, found COVID-19 cases in the world of 3,759,967 confirmed cases with 259,474 deaths. Data from the Ministry of Health on 9 May 2020 found COVID-19 cases in the Southeast Asia Regional of 86,294 confirmed cases with 3,075 cases died. WHO data on May 8, 2020, also shows that in Indonesia there were 12,776 confirmed cases of COVID-19 with 930 deaths with transmission classification as community transmission ${ }^{4,5}$. Whereas on May 11, 2020, COVID-19 cases in Indonesia found 14,032 confirmed cases with 973 deaths ${ }^{1}$. Data from the Ministry of East Java Provincial Government Data obtained 1281 confirmed cases with 141 died $^{6}$. East Java Provincial Government Circular on April 16, 2020, regarding the appeal for worship at home, working at home, and studying at home and extending ${ }^{3}$. Health and medical education in China have stopped university education and nursing practice based on the evidence-based approach is found in a small number of institutions $(13.2 \%)^{7}$. Some health schools in China formally cancel formal teaching in hospitals, have their exams suspended, and hinder the education of health students in the face of a pandemic, as well as in Canada, the effects of the Pandemic virus restriction cause cessation of clinical practice and choice for students for up to 6 weeks $^{8}$. Cui's research results in 2018 showed that the effectiveness of evidence-based nursing is superior to traditional teaching in students' critical thinking 9 . Competence in practice using evidence-based practice or journal sharing is better than other method ${ }^{10}$. The health university in Kediri City has dismissed its students to study at home, but the learning process must still be carried out ${ }^{11}$. STIKES Kediri Baptist Hospital has also closed students and carry out learning from home. The need for innovation related to the learning process of nursing students who are also supposed to practice in hosp. The role of lecturers in facing the challenges of using e-learning fully without using conventional method (lectures) during COVID-19 needs to make innovations that focus on student activity. The use of e-learning method, in full without any physical interaction (lecture method) requires a student- focused learning approach. The use of sharing journals can improve student self-efficacy, increase information literacy, improve perceptions of evidence-based practice (EBP), and intrinsic academic motivation to experience stimulation, and can predict the future implementation of EBP ${ }^{7,12-14}$. Satisfaction increased significantly in satisfaction surveys that were routinely collected over one year related to the curriculum by providing material related to evidence-based nursing practice ${ }^{15}$. The results of previous studies show that overall, there is no significant difference between groups with e-learning and conventional learning or face-to-face relating to the knowledge, skills, and satisfaction of nursing students, and also E-learning can be used in offering alternative education method ${ }^{15-17}$. The study uses an e-learning model with a journal sharing approach to work on nursing care reports, measure competence, and exam results in critical nursing periods. Students do a Journal Sharing or research results to students to be able to do indepth analysis related to interventions or measuring tools obtained through journals and are expected to improve the quality of care and get the best means of intervention or measuring tools in carrying out nursing care in the critical nursing area. Implementation of EvidenceBased Practice Nursing must continue to be developed, implemented, and evaluated using validated method including the use of best practice standards ${ }^{18}$. Learning to students using method like this needs to be developed to improve the quality of applications of research results in the area of health services. Learning method don't have to be classed, can also use online media through e-learning to apply evidence-based practice using JSCC. Traditional learning in the class can be transferred to online media and is inseparable from the learning styles of students. Students feel that online programs can meet their needs in learning. Lecturers applying technological innovation in nursing education require an understanding of learning directly to students so they can satisfy and meet the needs of students

\section{Materials and Method}

The study uses a descriptive-analytic research design. Descriptive Analytic Research was to use crossectional research that analyses deeply related to several variables studied. The purpose of this study was to analyze the E-Learning Innovation: Journal of Sharing of Critical Care (JSCC) in Critical Nursing Students during the Pandemic Period of COVID-19. The study population was all final-year nursing students at STIKES Kediri Baptist Hospital. The research sample was nursing 
students at the final level of Nursing at STIKES Baptist Hospital in Kediri using the Total Sampling Technique. Total Sampling is a sampling technique that uses the entire population as research respondents. The sample size of this study was 39 respondents. The independent variable of the study is critical nursing competency. Implementation of JSCC for 6 weeks, with a load of 6 critical nursing care. JSCC procedures namely 1) The learning process using paid edlink applications (https:// edlink.id/login) 2) students get pseudo cases of critical patients through e-learning 2) students conduct critical nursing assessments based on case theory or diagnostic prognosis, primary assessment, and diagnostic procedures 3) students make nursing care through Main complaint assessment, problem priority analysis, outcome nursing care plan, nursing care plan, 4) students determine interventions by comparing interventions or measuring tools based on journals or research results and sharing them through video conversion with students and other lecturers 5) after students implement JSCC 6 months the students assessed Fatigue, competency and exam score scores. This research was conducted data collection from March to April 2020. Data collection using questionnaires based on Edlink Application and Google Form. The scoring technique uses an interval data scale from 0-10 (less to very good). The results of the study were tabulated and coded and then analyzed using Partial least square (PLS). The study has obtained a letter of ethics clearance from the Chakra Brahmanda Lentera Institute with letter number 001/25/V/EC/ KEPK/Lemb.Candle/2020.

\section{Results and Discussion}

Results: Measurement of the outer reflective model using reliability and validity. Reliability using Cronbach's alpha with a minimum value of 0.7 , the value on the outer loadings obtained the latent variable value (the ability to explain the theory, primary assessment, diagnostic procedure, nursing care, soft skills, and outcome) $\geq 0.7$. Convergent validity using the average variance extracted (AVE) value with a value of $\geq 0.5$, which means that this value describes sufficient convergent validity and means that one latent variable can explain more than half of the variance of the indicators on the average. The results showed that composite reliability, which is a group of indicators measuring a variable, has good composite reliability because it has a composite reliability $\geq 0.7$. The results showed that the Goodness of fit model was measured using the R-square dependent latent variable with the same interpretation as regression. Q-Square predictive relevance for structural models measures how well the observed value is generated by the model and also its parameter estimates. The value of Q-square $>0$ indicates that the model has predictive relevance, otherwise, if the value of Q-square $\leq 0$ indicates that the model lacks predictive relevance. The results showed that the results of T-statistics with $\alpha=5 \%$ and $\mathrm{t}=1.96$, obtained a variable $\mathrm{T}$ statistic $>1.96$ with a positive original sample estimate, so all variables have a positive relationship between variables (The ability to make nursing care with Soft skill; Soft skill with Outcome; Outcome with Soft skill).

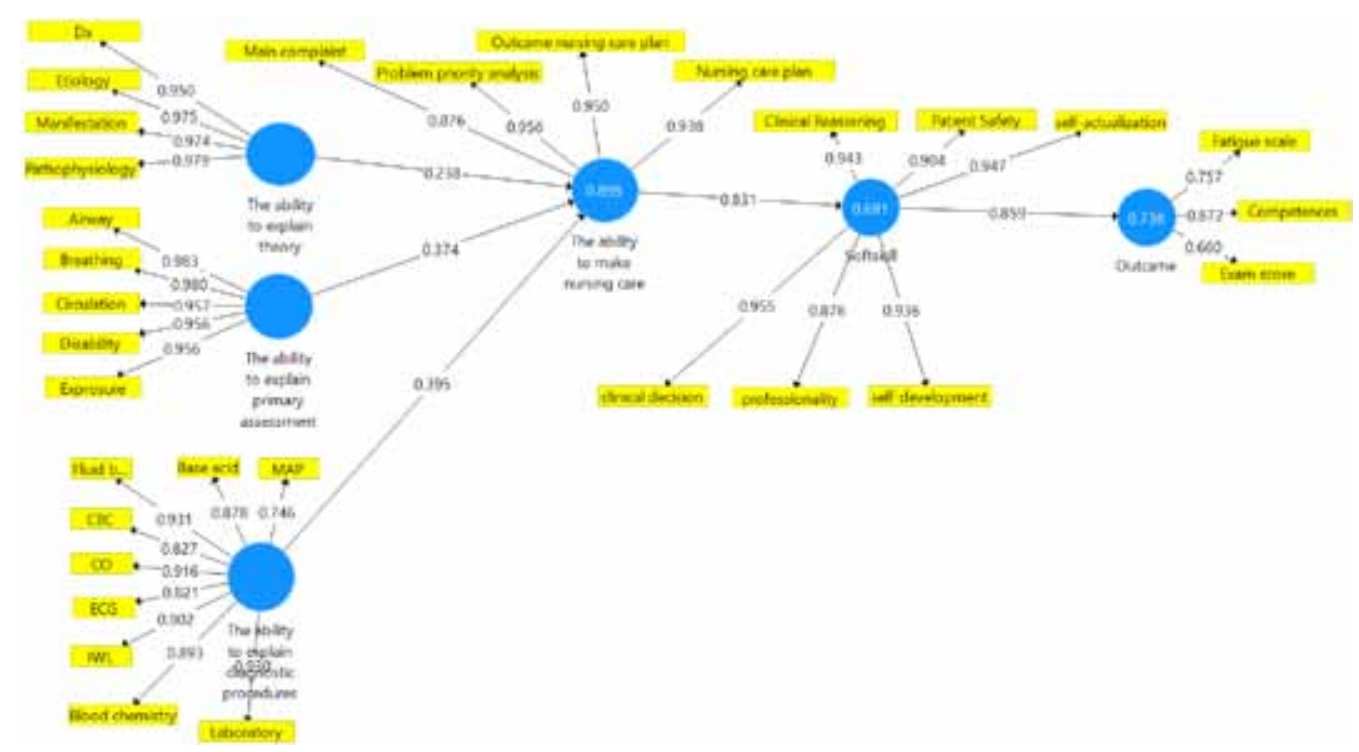

Figure 1. PLS E-learning "Journal Sharing of Critical Care (JSCC)" 
Table 1. Variable Test Results using PLS

\begin{tabular}{|l|c|c|c|c|c|c|c|c|}
\hline Variable & $\begin{array}{c}\text { R } \\
\text { square }\end{array}$ & $\begin{array}{c}\text { R square } \\
\text { adjusted }\end{array}$ & $\begin{array}{c}\text { Cronbach } \\
\text { alfa }\end{array}$ & $\begin{array}{c}\text { Composite } \\
\text { reliability }\end{array}$ & AVE & $\begin{array}{c}\text { Original } \\
\text { sample }\end{array}$ & $\begin{array}{c}\text { T } \\
\text { statistic }\end{array}$ & $\begin{array}{c}\text { p } \\
\text { Value }\end{array}$ \\
\hline The ability to explain theory & - & - & 0,979 & 0,984 & 0,940 & & & \\
\hline $\begin{array}{l}\text { The ability to explain primary } \\
\text { assessment }\end{array}$ & - & - & 0,982 & 0,986 & 0,934 & & & \\
\hline $\begin{array}{l}\text { The ability to explain diagnostic } \\
\text { procedures }\end{array}$ & - & - & 0,960 & 0,966 & 0,763 & & & \\
\hline The ability to make nursing care & 0,985 & 0,886 & 0,948 & 0,963 & 0,866 & 0,985 & 25,273 & 0,000 \\
\hline Softskill & 0,691 & 0,682 & 0,967 & 0,973 & 0,860 & 0,690 & 8,15 & 0,000 \\
\hline Outcame & 0,738 & 0,731 & 0,665 & 0,810 & 0,590 & 0,738 & 9,267 & 0,000 \\
\hline
\end{tabular}

\section{Discussion}

The results showed that there was a strong relationship and validity and reliability were confirmed for each latent variable. The strong relationship between the ability to explain the theory to the ability to make nursing care, this explains that the ability of students to explain theory through e-learning using the edlink application in the journal sharing of critical care model in the practice of the nursing profession shows validity, reliability, and relationships strong and positive. The ability of students to explain the theory. Students can explain the concepts of medical diagnosis, etiology, clinical manifestations, pathophysiology $(\mathrm{p}=0,000)$. Students understand medical diagnosis in critical nursing using the JSCC E-learning model. Students demonstrate their ability to complete assignments, pre convergence assessment results, and video conferencing post conferences. Lecturers give questions related to cases theoretically and direct students in understanding the etiology of diagnostic problems, clinical manifestations to the course of the disease to have an impact on subsequent nursing care. Students can understand the signs and symptoms of the case and refer to it as major and minor data to establish a nursing diagnosis. Nursing care is inseparable from the ability of students to understand the basic medical diagnosis cases that arise, students can see the prognosis of the disease, and the direction of the disease will develop.

The results also showed that there was a close and positive relationship between the ability to explain the primary assessment and the ability to make nursing care. The ability of students in conducting critical nursing care assessments by conducting primary assessment studies including airway studies, breathing studies, circulation studies, disability studies, and exposure studies. Critical nursing students must be able to perform competencies or actions for each primary assessment carried out, this is important because it deals with critical conditions in patients. A close and positive relationship based on statistics shows that students studying during the Pandemic COVID-19 period were still able to have the standardized abilities of higher education in health Baptist hospital health colleges in Kediri. Students learn from home but they can carry out assignments and achieve predetermined primary assessment competencies. Teaching online research does not improve attitudes toward research, but nursing students report an increase in understanding of research terminology ${ }^{19-21}$. Critical care nursing research tends to increase collaboration with patients and families, illustrating the shift towards user values ${ }^{22-24}$. Students in conducting nursing care also focus on the primary assessment that has been done. Nursing care plans made by students must be based on a journal or research results. Students use evidence-based practice and are directed as needed for each primary assessment that has been obtained. JSCC allows students to analyze journals using PICO (population, intervening, control, outcome) data extraction and is compared to each nursing care plan that will be provided.

The results showed that there was a relationship with a strong and positive relationship between the ability to explain diagnostic procedures and the ability to make nursing care $(p=0,000)$. Students get pseudo cases through e-learning media with the method of journal sharing for critical care. Students analyze laboratory and diagnostic results to analyze the relationship with problems that occur in patients. Students connect the 
problem of abnormal conditions related to the diagnostic results obtained and finally determine the problems in nursing care. Students make follow-up plans for nursing care based on evidence-based practice following the problems found. Educational interventions to improve the competence of mentors must be designed 16,25,26. Evidence-based practice is very important for nursing education because Florence Nightingale is a pioneer of evidence-based practice and technology is a key component of the evolution of evidence-based practice ${ }^{27,28}$ Diagnostic procedures that were analyzed included abnormal values of cardiac output, fluid balance, acidbase, blood chemistry, IWL, mean arterial pressure, fluid balance, and CBC.

The results showed that the ability to make nursing care with soft skills had a strong and positive relationship $(P=0,000)$. Sub variables that are in it indicate that there are a high validity and reliability related to the making of nursing care with the ability of students in the realm of soft skills. The ability of students in making nursing care has sub-variables as a measuring tool including the meaning of the main complaints, analysis of priority problems, the objectives of nursing care, and planning of interventions based on evidence-based practice. Students can also achieve their soft skills in the form of clinical reasoning skills, patient safety, self-development, and self-actualization. Students plan critical nursing care in a structured manner with an evidence-based practice approach from sharing journals that have been made previously. E-learning based learning method for students of the critical nursing profession with a journal sharing of critical care approach in the area of intensive care to improve evidence-based understanding based on practice must be carried out due to the existence of Pandemic COVID-19 which makes students unable to achieve their competence in the practice field and have an impact on learning conditions ${ }^{22,29}$. This learning method shows the existence of learning preferences, interactive learning, course design, patient safety, and future learning needs. The e-learning program captures the learning styles and needs of students. Evidence-based practice underscores the modern approach to nursing to ensure the provision of safe, up-to-date, and personcentered care in a developing clinical environment.

Professional students at the critical nursing stage carry out nursing care with secondary and primary data. Students generally do nursing care without using research or journal results when doing nursing care. But at this time because there is a Pandemic, students use secondary data and the use of journals without doing practice. Students are more focused on conventional nursing care in general, which makes sharing information related to research results less. Journal sharing is expected to increase knowledge and information related to new things from information that can be applied to nurses based on evidence. Critical nursing care by sharing journals with students, students can be more exposed and easier to understand in doing nursing care with the best action on patients. Evidencebased practice can support the nursing profession to ensure the provision of safe, current, patient-centered care $^{15,30}$. The nursing curriculum includes this as a good learning method for students and easy internet access in implementing it. Lecturers and students are connected in a flow and can discuss well related critical care to be provided. Professional students will further enhance the understanding between evidence and clinical practice and will ultimately increase self-confidence in students when students take care of patients in clinical settings. The learning method for professional students is by sharing a journal of Critical Care (JSCC). In the condition of Pandemic COVID 19 online student learning method based on professional profession. Digital learning innovation method with online media can be used. The method of the Sharing Journal of Critical Care (JSCC) can still be used with students conducting a journal analysis and making nursing care based on evidencebased practice.

The results also showed that the ability of the student soft skill to influence the outcome was in the form of the final score of the critical nursing competency test and the level of student fatigue. Higher education bridges the practice gap in increasing knowledge, through learning method using journal sharing of critical care based on evidence-based practice to remind knowledge of college students. Findings from small-scale research studies also indicate that e-learning does meet a variety of learning styles and the needs of nursing students, but we all also understand that online learning alone is not enough nor should a mixed approach to learning also be adopted to meet and bridge the gap in theoretical practice which supports the integration of knowledge into clinical practice. The application of the Journal of Sharing of Critical Care needs to also understand changes to research ideas that have been formed beforehand into something accessible and useful, clear links between research and clinical and professional nursing practice, comments on subject and learning formats, improved 
skills in search and exploration effective evidence, and improvement for the future. The evidence-based practice supports nursing to ensure the provision of safe, current, and patient-centered care The critical nursing curriculum includes evidence-based research but students often have difficulty understanding the relevance of research ${ }^{15}$. Making the connection between research and clinical practice open to students increases their overall satisfaction. Improving understanding between clinical evidence and practice increases student confidence in questioning the clinical practice.

Models based on sharing journals or based on evidence in nursing care offer academic support and coping strategies in advanced nursing programs. (Cantwell et al., 2020). The American Association of Colleges supports active learning strategies and strategies must also use student-centered strategies ${ }^{17,31}$. Although the surveyed nursing students reported moderate ability beliefs, their intention to adopt and integrate EBP in their future nursing practices was relatively high (Labrague et al., 2020). Evidence-based nursing is an important competency for nurses to provide high-quality care. Various educational efforts to improve the evidencebased practice of nurses are ongoing internationally ${ }^{13}$. An evidence-based practice curriculum can be combined and integrated with core nursing courses. Implementing blended learning in EBP education among nursing students is effective.

\section{Conclusion and Acknowledgment}

Conclusion: The ability to explain the theory, the ability to explain primary assessment, The ability to explain diagnostic procedures have a strong and positive relationship to the ability to make nursing care. Students can make nursing care that has a positive impact on Soft Skills, and Outcome.

Acknowledgments: We thank the Ministry of Science, Research, Technology, and Higher Education of Indonesia (RISTEKDIKTI RI) for Research Grants 2019 and providing 2020. We thank you to the Director of the Baptist Hospital Collage in Kediri and all research respondents.

Ethical Clearance: Ethical Clearance has taken form from the Chakra Brahmanda Lentera Institute with letter number 001/25/V/EC/KEPK/Lemb.Candle/2020.

Source of Funding: This research is the result of a research grant from the Ministry of Education and Technology in 2019 and Implementation in 2020.
Conflict of Interest: This Research has no conflict of interest

\section{Reference}

1. GTPP. Gugus Tugas Percepatan Penanganan COVID-19: Data Sebaran COVID-19. Republik Indonesia 2020; 1.

2. WHO. WHO Coronavirus Disease (COVID-19) Dashboard. World Health Organization 2020; 1.

3. Gubernur. Perpanjangan pelaksanaan kebijakan pendidikan dalam Masa Darurat Penyebaran Corona Virus Disease (COVID-19) di Jawa timur. Surabaya, 2020.

4. Kaldan G, Nordentoft S, Herling SF, et al. Evidence characterising skills, competencies and policies in advanced practice critical care nursing in Europe: a scoping review protocol. BMJ Open 2019; 9: e031504.

5. WHO. Coronavirus disease (COVID-19): Situation Report-109. 2020.

6. Prov.JATIM. JATIM Tanggap COVID-19. Republik Indonesia 2020; 1.

7. Song CE, Kim WG, Lim YJ. An analysis of evidence-based practice courses in Korean nursing education systems. Heliyon 2019; 5: e02650.

8. Ahmed H, Allaf M, Elghazaly H. COVID-19 and medical education. Lancet Infect Dis 2020; 1: 1.

9. Cui C, Li Y, Geng D, et al. The effectiveness of evidence-based nursing on development of nursing students' critical thinking: A meta-analysis. Nurse Educ Today 2018; 65: 46-53.

10. Sánchez-García I, Ureña Molina M del P, LópezMedina IM, et al. Knowledge, skills and attitudes related to evidence-based practice among undergraduate nursing students: A survey at three universities in Colombia, Chile and Spain. Nurse Educ Pract 2019; 39: 117-123.

11. Suwardianto H, Prasetyo A, Utami RS. Effects of physical-cognitive therapy (PCT) on criticaly ill patients in intensive care unit. Hiroshima $\mathrm{J}$ Med Sci; 67.

12. Labrague LJ, McEnroe-Petitte D, D'Souza MS, et al. Capability beliefs and the intention to adopt evidence-based practices in the future among nursing students: An international study. J Prof Nurs. Epub ahead of print 2020. DOI: https://doi. org/10.1016/j.profnurs.2020.01.006. 
13. Oh EG, Yang YL. Evidence-based nursing education for undergraduate students: A preliminary experimental study. Nurse Educ Pract 2019; 38: $45-51$.

14. Amit-Aharon A, Melnikov S, Warshawski S. The effect of evidence-based practice perception, information literacy self-efficacy, and academic motivation on nursing students' future implementation of evidence-based practice. J Prof Nurs. Epub ahead of print 2020. DOI: https://doi. org/10.1016/j.profnurs.2020.04.001.

15. Disler RT, White H, Franklin N, et al. Reframing evidence-based practice curricula to facilitate engagement in nursing students. Nurse Educ Pract 2019; 41: 102650.

16. Mikkonen $\mathrm{K}$, Tomietto $\mathrm{M}$, Cicolini $\mathrm{G}$, et al. Development and testing of an evidence-based model of mentoring nursing students in clinical practice. Nurse Educ Today 2020; 85: 104272.

17. AACN. Making the Pivot: Online Learning During COVID-19. American Assoxiation of Colleges of Nursing 2020; 1.

18. Gullick J, Lin F, Massey D, et al. Structures, processes and outcomes of specialist critical care nurse education: An integrative review. Aust Crit Care 2019; 32: 331-345.

19. Ramsay A, Wicking K, Yates K. In what ways does online teaching create a positive attitude towards research in nursing students studying a first year evidence-based practice undergraduate subject online? Nurse Educ Pract 2020; 44: 102744.

20. Suwardianto H. Cognitive therapy dengan pendekatan symptom management theory di intensive care unit rs. Baptis kediri. J Penelit Keperawatan; 4.

21. Suwardianto H, Rimawati. Explicit Instruction Model (EIM): Daily Training Emergencies Preparedness (DTEP) Toward Skills of Participants the Youth Red Cross. Conf 2nd Jt Int 2018; 2: 403410 .
22. Egerod I, Kaldan G, Lindahl B, et al. Trends and recommendations for critical care nursing research in the Nordic countries: Triangulation of review and survey data. Intensive Crit Care Nurs 2020; 56: 102765.

23. Suwardianto H, Selvia D. Buku Ajar Keperawatan Kegawatdaruratan (Perspektif, Konsep, Prinsip, dan Penatalaksanaan Kegawatdaruratan). Surabaya: PT. REVKA PETRA MEDIA, 2015.

24. Suwardianto H, Andynugroho YC. Kemandirian Fungsional Lansia Diabetes Melitus Di Kelurahan Bangsal Kota Kediri. J STIKES RS Baptis Kediri; 9.

25. Suwardianto H, Prasetyo A, Utami RSu. Physical Function-Tardive Dyskenesia (PATD) on Critical Patients in Intensive Care Unit. J Ners; 12. Epub ahead of print 2017. DOI: http://dx.doi. org/10.20473/jn.v12i2.4504.

26. Suwardianto H, Sari D. Environmental Factors of Sleep Hygiene That Influence The Level of Pain on Criticall ill Patients in Intensive Care Unit. Str J Ilm Kesehat; 9. Epub ahead of print 3 May 2020. DOI: 10.30994/sjik.v9i1.266.

27. Mackey A, Bassendowski S. The History of Evidence-Based Practice in Nursing Education and Practice. J Prof Nurs 2017; 33: 51-55.

28. Klimes R. Relaxation Therapy: Theory \& Practice, http://www.learnwell.org/relax.htm.

(2010, accessed 1 January 2015).

29. Lahti M, Hätönen $H$, Välimäki M. Impact of e-learning on nurses' and student nurses knowledge, skills, and satisfaction: A systematic review and meta-analysis. Int J Nurs Stud 2014; 51: 136-149.

30. Sánchez Expósito J, Leal Costa C, Díaz Agea JL, et al. Ensuring relational competency in critical care: Importance of nursing students' communication skills. Intensive Crit Care Nurs 2018; 44: 85-91.

31. Marianne. About critical care nursing. Am Assoc Crit Nurses 2016; 1. 